\title{
Foraging Behavior of Apis mellifera L. Landraces Under Terai Condition of Nepal
}

\author{
S. Parajuli and R.B. Thapa \\ Institute of Agriculture and Animal Science \\ Tribhuvan University, Rampur, Chitwan \\ e:mail:psangeeta16@gmail.com
}

\begin{abstract}
A study was conducted to compare the foraging behavior of landraces of Apis mellifera L. under Terai condition of Nepal, for which the honeybee colonies were brought from Dang, Chitwan, Sarlahi and Parsa districts. The experiment was laid out in a randomized complete block design (RCBD) with six replications (colonies) and four treatments (landraces), i.e. Apis mellifera carnica, Apis mellifera russian, Apis mellifera buckfast and Apis mellifera ligustica. Each experimental unit consisted of 10 frame Langstroth bee hives with about 50,000 workers. Data recording continued from 26 March to 14 July in Chitwan. The landrace A.m. buckfast had the highest out-going foragers/5min (115.667 workers/ colony) significantly higher than A.m. carnica (73.500 workers/colony), A.m. russian (52.667 workers/colony) and A.m. ligustica (48.667 workers/colony), respectively. Similarly, the average number of foragers (in-coming with nectar/5min) was recorded the highest in A.m. buckfast (104.501 workers/colony) which was 1.46, 1.63, 1.78 times higher than A.m. carnica, A.m. russian, A.m. ligustica, respectively. Therefore, A.m. buckfast and A.m. carnica colonies were the best performers in relation to foraging behavior among the four evaluated land races during spring and summer seasons under Terai condition of Nepal.
\end{abstract}

Key words: European bee, in-coming foragers, nectar, out-going foragers, pollen

\section{Introduction}

Beekeeping with Apis mellifera $\mathrm{L}$. is becoming more popular and is spreading in Terai and Mid hills of Nepal due to its higher honey productivity, more gentleness and less absconding behavior as compared to the native bee A. cerana Fab. (Shivakoti \& Bista 1999, Partap 1997). Nepal Agricultural Perspective Plan (APP 1995) has recognized beekeeping as high value income generating enterprise. Poor, marginal and even landless farmers can benefit from beekeeping to support their livelihoods as it can be started even with limited resources adding income and supplying nutrition to them (ICIMOD 1999). Bees being haplodiploid and highly open mating creatures in nature, their outcrossing and inbreeding among and within subspecies for several generations develop genetically variable landraces of different values (Moritz 1980). Inbreeding depression is becoming one of the challenging problems due to the loss of their economic potentials in many A. mellifera apiaries in Nepal. Therefore, beekeepers are facing many problems, such as loss of vigor and defensive power, poor hygienic behavior, reduced body size, more swarming and supersedure, frequent incidences of pests and diseases, all of them contribute to unproductive and weak colonies (Shivakoti \& Bista 1999). To overcome these problems and producing large amount of honey which is very high in quality (Anderson et al. 1983, Horr 2000), higher number of healthy field force is a prerequisite prior to honey flow season (Morse \& Hopper 1985, Bhusal 2003), which can be achieved only through proper selection of landraces of $A$. mellifera (Verma 1995). In absence of such work, whatever the inputs and efforts are made for enhancing honey productivity and quality all will be disappointing. Superior genotypes of $A$. mellifera landraces can provide high foraging force during honey flow season through which problem, like loss of vigor, defensive power, poor hygienic 
behavior; reduced body size, more swarming and supersedure, frequent incidences of pests and diseases can be minimized easily.

\section{Methodology}

Different landraces of A. mellifera were collected from Dang, Chitwan, Sarlahi and Parsa based on the information from respective District Agriculture Development Offices. Four superior stocks having diverse morphometric, phenotypic and higher economic values were selected for evaluation. Those races were A. m. carnica, A. m. ligustica, A. m. buckfast, and $A$. $m$. russian. There may be genetic error in the races and purelines, which were not maintained.The daughter queens of the respective races, were produced by the grafting method. The experiment was carried out in RCBD with four treatments and six replications. Each hive with ten framed colonies of cross breed, A. mellifera . was considered as an experimental unit. The different races used as treatments were:

i) Apis mellifera carnica: 6 hives (10 frame bees with approx. 50,000 workers).

ii) Apis mellifera ligustica: 6 hives (10 frame bees with approx. 50,000 workers).

iii) Apis mellifera buckfast: 6 hives (10 frame bees with approx. 50,000 workers).

iv) Apis mellifera russian: 6 hives (10 frame bees with approx. 50,000 workers).

The colonies for this experiment were prepared in 10 framed wooden Langstroth beehive. The newly mated queens were introduced to the respective experimental colonies having 10 combs of bees as original colony strength (2010/2/15). Experimental colonies were fed sugar syrup solution (1:1) 1 liter/colony in alternate day to enhance more brood production in advance to make colonies stronger. The experiment was first initiated at IAAS, Rampur on March during (Spring) Litchi (Litchi chinensis Sonn) flowering. After the blooming period of Litchi, the experimental colonies were migrated to Padampur (Eastern Chitwan) at the beginning of May, during Padke (Albizzia julibrissin Durazz) flowering. The bees were again migrated (rainy season) to Mangalpur near IAAS during wild cucumber (Maraha gilennis Green) flowering and maize (Zea mays L.) flowering at the last week of June. Then after, experimental colonies were migrated (autumn season) to Dang (September 15, 2010) during Chiuri (Aesandra butryacea Roxb) flowering to collect honey in the month of October. The number of foragers out-going from hive, returning to hive with nectar or pollen load were counted per 5 minutes at the hive entrance at an interval of 21 days at peak foraging time of the day and peak flowering period of major bee flora from March to July. Peak foraging time of the day was estimated, when maximum number of workers were active for foraging and peak flowering was noted, when main flora was in between 40 to $50 \%$ of flowering. The observation in the morning started from 8:30 am and completed by 10: $30 \mathrm{am}$. During rainy days, the time of observation was delayed by 2 or 3 hours. There was no record of the mite population of different landraces.

\section{Results and Discussion}

This section deals about the results of the study conducted on foraging behavior of A.mellifera landraces under Terai condition of Nepal. Number of out-going foragers, in-coming foragers with nectar, incoming foragers with pollen were taken from March to July of different races. There were significant differences among the races.

\section{Out-going foragers}

The out-going forages differed with month and races. Average number of out-going foragers (worker bees/ colony) were found highest in A. mellifera buckfast. Oh and Choi (1986) found temperature dependent bee foraging. Foraging also decreases with increasing wind velocity and rain. Thus, foraging intensity depends to climate, i.e. rain, temperature, high humidity and wind velocity (Mishra 1995, Thapa \& Dangol 1987/ 88). A. m. buckfast had the highest number of outgoing foragers (125.389) followed by A. m. carnica, A. m. russian and A. m. ligustica (72.778) (Table 1).

Low temperature, high humidity and fogging weather caused food shortage, which ceased foraging (Entomology Division 1996). On $3^{\text {rd }}$ week of April, the lowest out-going foragers were recorded at 58.417 worker bees/colony, which decreased by $47.29 \%$ and increased by $24.32 \%$ at second week of May. They sharply increased (51.05\%) on the fourth week of June and decreased (23.31\%) on the second week of July. The out-going foragers differed significantly among the difference races of A. mellifera on the month of May (Table 1). Collectively, environmental factors outside the hive affect the honeybees activities in 
S. Parajuli \& R. B. Thapa/Foraging Behavior of Apis

collecting pollen and nectars as demonstrated by Lundie (1925) and Butler (1945). A. m. carncia had a strongly foraging instinct which occasionally lead to robbing among colonies.

Table 1. Variation on out-going foragers among different landraces of A. mellifera, Chitwan, 2010

\begin{tabular}{|c|c|c|c|c|c|c|c|}
\hline \multirow[b]{2}{*}{$\begin{array}{l}\text { Bee } \\
\text { races }\end{array}$} & \multicolumn{7}{|c|}{ Out-going foragers (numbers of bees per five minutes) } \\
\hline & $\begin{array}{c}3 \text { weeks } \\
\text { (March 26) }\end{array}$ & $\begin{array}{l}6 \text { weeks } \\
\text { (April 17) }\end{array}$ & $\begin{array}{l}9 \text { weeks } \\
\text { (May 9) }\end{array}$ & $\begin{array}{l}12 \text { weeks } \\
\text { (May 31) }\end{array}$ & $\begin{array}{l}15 \text { weeks } \\
\text { (June 23) }\end{array}$ & $\begin{array}{l}18 \text { weeks } \\
\text { (July 14) }\end{array}$ & $\begin{array}{c}\text { Treatment } \\
\text { mean }\end{array}$ \\
\hline A. $m$. & 111.667 & 60.833 & $73.500^{\mathrm{ab}}$ & $54.530^{\mathrm{b}}$ & 105.167 & 105.167 & \\
\hline carnica & $(2.034)$ & $(1.737)$ & $(1.805)$ & $(1.753)$ & $(1.994)$ & 1.994 & 85.144 \\
\hline A. $m$. & 118.333 & 63.000 & $52.667^{b}$ & $64.667^{b}$ & 110.500 & 73.500 & 80445 \\
\hline russian & $(2.018)$ & $(1.678)$ & $(1.617)$ & $(1.793)$ & $(1.976)$ & 1.750 & 80.445 \\
\hline A. $m$. & 129.833 & 74.167 & $115.667^{\mathrm{a}}$ & $96.667^{\mathrm{a}}$ & 86.167 & 249.833 & \\
\hline buckfast & (2.111) & (1.782) & $(2.010)$ & (1.87) & (1.914) & 2.063 & 125.389 \\
\hline A. $m$. & 83.500 & 35.667 & $48.667^{b}$ & $62.000^{\mathrm{b}}$ & 117.833 & 89.000 & 72778 \\
\hline ligustica & (1.914) & (1.441) & (1.623) & (1.78) & $(2.061)$ & 1.930 & /2.7/8 \\
\hline Mean & 110.833 & 58.417 & 72.625 & 69.458 & 104.917 & 129.375 & 90.939 \\
\hline $\operatorname{SEm}( \pm)$ & 0.058 & 0.163 & 0.115 & 0.057 & 0.087 & 0.139 & \\
\hline $\begin{array}{l}\text { LSD } \\
(0.05)\end{array}$ & NS & NS & 0.3459 & 0.1696 & NS & NS & \\
\hline $\mathrm{CV}(\%)$ & 7.031 & 24.055 & 15.982 & 29.440 & 10.663 & 17.581 & \\
\hline
\end{tabular}

Figures in the parenthesis are $\log$ transferred values ( $\log \mathrm{X}$ for values more than $10, \log (\mathrm{x}+1)$ for values less than 10 . Means followed by same letter (s) within the column are not significantly different by DMRT at $5 \%$.

\section{In-coming foragers with nectar}

In-coming foragers with nectar differed among the different races and also differed with time (Table 2). In-coming foragers of A. m. ligustica with nectar were the lowest (59.028 worker bees/colony) as compared to other races. It was higher in A. m. russian (8.42\%), A. m. carnica $(20.51 \%)$ and A. m. buckfast (77.04\%) as compared to A. m. ligustica. Average number of incoming foragers with nectar was the highest in $A$. mellifera buckfast (104.501). Calderone and Page
(1998) showed that the workers of the low strain returned to the hive carrying nectar loads with much greater frequency than did high-strain workers. Fundamental aspects of foraging behavior are species diversity preference, which bees may fly over a profitable path and perhaps more stimulating. This agrees with Gary et al. (1972). Nelson and Sturtevant (1924) reported that in-coming foragers with nectar depend upon the racial stock of the queen.

Table 2. Variation on in-coming foragers with nectar among different landraces of A. mellifera, Chitwan, 2010

\begin{tabular}{|c|c|c|c|c|c|c|c|}
\hline \multirow[b]{2}{*}{ Bee races } & \multicolumn{7}{|c|}{ In-coming foragers with nectar (numbers of bees per five minutes) } \\
\hline & $\begin{array}{c}3 \text { weeks } \\
\text { (March 26) }\end{array}$ & $\begin{array}{l}6 \text { weeks } \\
\text { (April 17) }\end{array}$ & $\begin{array}{l}9 \text { weeks } \\
\text { (May 9) }\end{array}$ & $\begin{array}{l}12 \text { weeks } \\
\text { (May 31) }\end{array}$ & $\begin{array}{l}15 \text { weeks } \\
\text { (June 23) }\end{array}$ & $\begin{array}{l}18 \text { weeks } \\
\text { (July 14) }\end{array}$ & $\begin{array}{c}\text { Treatment } \\
\text { mean }\end{array}$ \\
\hline $\begin{array}{l}\text { A. m. } \\
\text { carnica }\end{array}$ & $\begin{array}{l}67.000^{b} \\
(1.815)\end{array}$ & $\begin{array}{c}46.333^{b} \\
(1.642)\end{array}$ & $\begin{array}{l}53.500^{b} \\
(1.667)\end{array}$ & $\begin{array}{l}71.500 \\
(1.836)\end{array}$ & $\begin{array}{l}45.667^{\mathrm{b}} \\
(1.588)\end{array}$ & $\begin{array}{c}142.833^{\mathrm{a}} \\
(2.149)\end{array}$ & 71.139 \\
\hline A.m. & $81.000^{\mathrm{ab}}$ & $44.000^{\mathrm{b}}$ & $55.167^{b}$ & 58.500 & $83.167^{b}$ & $62.167^{b}$ & \\
\hline Russian & $(1.899)$ & $(1.619)$ & $(1.678)$ & $(1.642)$ & $(1.833)$ & $(1.709)$ & 64.000 \\
\hline A.m. & $108.000^{\mathrm{a}}$ & $110.67^{\mathrm{a}}$ & $109.833^{\mathrm{a}}$ & 77.000 & $161.333^{\mathrm{a}}$ & $60.167^{b}$ & \\
\hline buckfast & $(2.024)$ & $(2.022)$ & $(2.027)$ & $(1.858)$ & $(2.203)$ & (1.636) & 104.501 \\
\hline A.m. & $47.667^{c}$ & $47.500^{b}$ & $53.667^{\mathrm{b}}$ & 51.500 & $62.333^{b}$ & $91.500^{\mathrm{ab}}$ & \\
\hline ligustica & (1.667) & (1.577) & (1.708) & (1.667) & (1.742) & $(1.936)$ & 59.028 \\
\hline Mean & 75.917 & 62.000 & 61.708 & 64.625 & 88.125 & 89.167 & 74.667 \\
\hline $\operatorname{SEm}( \pm)$ & 0.043 & 0.094 & 0.211 & 0.104 & 0.120 & 17.354 & \\
\hline $\operatorname{LSD}(0.05)$ & 0.129 & 0.283 & 0.281 & NS & 0.361 & 0.350 & \\
\hline CV (\%) & 5.631 & 13.512 & 12.873 & 14.524 & 15.935 & 15.351 & \\
\hline
\end{tabular}

Figures in the parenthesis are $\log$ transferred values $(\log \mathrm{X}$ for values more than $10, \log (\mathrm{x}+1)$ for values less than 10 . Means followed by same letter (s) within the column are not significantly different by DMRT at 5\%. 
On an average, in-coming foragers with nectar during the last week of March was 75.917 worker bees /colony, which declined up to $2^{\text {nd }}$ week of May by $18.72 \%$ and slightly increased with $4.73 \%$ by the end of May, $36.36 \%$ by $3^{\text {rd }}$ week of June and only by $1.18 \%$ by mid of July. This was associated with the availability of nectar forage. There was positive correlation between availability of nectar and in-coming foragers with nectar.

\section{In-coming with pollen}

In-coming forgers with pollen were highly variable on different months but with little variations among the four races of $A$. mellifera (Table 3 ). In-coming foragers with pollen on last week of March was 54.458 worker bees/colony which decreased by $17.60 \%$ on $3^{\text {rd }}$ week of April and increased by 37.51 and 29.17\%, respectively on $2^{\text {nd }}$ and last week of May with slight decrease $(5.54 \%)$ on $3^{\text {rd }}$ week of June and sharply declining (50.19\%) by mid of July. Average number of in-coming foragers with pollen were the lowest in $A$. m. carnica (49.472 worker bees/colony) and A. m. russian, $A$. $m$. buckfast and A. m. ligustica had 6.57, 36.61 and $27.06 \%$ higher in-coming foragers with pollen. In-coming foragers with pollen were higher during $15^{\text {th }}$ weeks collecting maize pollen, whereas during $3^{\text {rd }}$ weeks they foraged on litchi flora having very short duration of flowering. Behavioral variation among sub families of bees has been found for pollen foraging (Calderone \& Page 1988), foraging distance (Oldroyd et al. 1993) and floral resource preference thus demonstrating heritable variation for these traits. The pollen-hoarding trait (storing pollen in the nest) has relatively high heritability and can be selected as a colony-level phenotype (Helmich et al. 1985). Thus, high and low pollen-hoarding strains of honeybees have been established by selecting for the amount of pollen stored in the combs (Page \& Fondrk 1995). Highstrain foragers individually are more likely to return from foraging trips with loads of pollen than are workers of low pollen-hoarding strains (Calderone \& Page 1988).

Table 3. Variation on in-coming foragers with pollen among different landraces of A. mellifera, Chitwan, 2010

\begin{tabular}{|c|c|c|c|c|c|c|c|}
\hline \multirow[b]{2}{*}{ Bee races } & \multicolumn{7}{|c|}{ In-coming foragers with pollen (numbers of bees per five minutes) } \\
\hline & $\begin{array}{c}3 \text { weeks } \\
\text { (March 26) }\end{array}$ & $\begin{array}{l}6 \text { weeks } \\
\text { (April 17) }\end{array}$ & $\begin{array}{l}9 \text { weeks } \\
\text { (May 9) }\end{array}$ & $\begin{array}{l}12 \text { weeks } \\
\text { (May 31) }\end{array}$ & $\begin{array}{l}15 \text { weeks } \\
\text { (June 23) }\end{array}$ & $\begin{array}{l}18 \text { weeks } \\
\text { (July 14) }\end{array}$ & $\begin{array}{c}\text { Treatment } \\
\text { mean }\end{array}$ \\
\hline A. m. carnica & $\begin{array}{c}47.000^{\mathrm{bc}} \\
(1.637)\end{array}$ & $\begin{array}{c}25.833^{b} \\
(1.305)\end{array}$ & $\begin{array}{l}54.667 \\
(1.452)\end{array}$ & $\begin{array}{c}71.667^{\text {ab }} \\
(1.836)\end{array}$ & $\begin{array}{l}62.000 \\
(1.710)\end{array}$ & $\begin{array}{l}35.667^{\mathrm{a}} \\
(1.549)\end{array}$ & 49.472 \\
\hline A. m. Russian & $\begin{array}{c}61.667^{\mathrm{ab}} \\
(1.769)\end{array}$ & $\begin{array}{l}52.833^{\mathrm{a}} \\
(1.677)\end{array}$ & $\begin{array}{l}62.167 \\
(1.625)\end{array}$ & $\begin{array}{l}64.333^{\mathrm{b}} \\
(1.718)\end{array}$ & $\begin{array}{r}64.500 \\
(1.529)\end{array}$ & $\begin{array}{l}10.833^{b} \\
(0.897)\end{array}$ & 52.722 \\
\hline A. m. buckfast & $\begin{array}{l}70.167^{\mathrm{a}} \\
(1.814)\end{array}$ & $\begin{array}{l}22.500^{b} \\
(1.205)\end{array}$ & $\begin{array}{l}66.167 \\
(1.749)\end{array}$ & $\begin{array}{c}120.833^{\mathrm{a}} \\
(2.078)\end{array}$ & $\begin{array}{l}79.167 \\
(1.806)\end{array}$ & $\begin{array}{l}46.667^{\mathrm{a}} \\
(1.490)\end{array}$ & 67.584 \\
\hline $\begin{array}{l}\text { A. m. } \\
\text { ligustica }\end{array}$ & $\begin{array}{l}39.000^{\mathrm{C}} \\
(1.582)\end{array}$ & $\begin{array}{l}60.000^{\mathrm{a}} \\
(1.707)\end{array}$ & $\begin{array}{l}63.833 \\
(1.569)\end{array}$ & $\begin{array}{l}62.000^{\mathrm{b}} \\
(1.751)\end{array}$ & $\begin{array}{l}95.500 \\
(1.933)\end{array}$ & $\begin{array}{l}56.833^{\mathrm{a}} \\
(1.702)\end{array}$ & 62.861 \\
\hline Mean & 54.458 & 44.875 & 61.708 & 79.708 & 75.292 & 37.500 & 58.160 \\
\hline $\operatorname{SEm}( \pm)$ & 0.058 & 0.140 & 0.211 & 0.087 & 0.177 & 0.086 & \\
\hline LSD (0.05) & 0.174 & 0.268 & NS & 0.261 & NS & 0.261 & \\
\hline CV $(\%)$ & 11.956 & 23.271 & 32.412 & 16.303 & 24.904 & 25.645 & \\
\hline
\end{tabular}

Figures in the parenthesis are $\log$ transferred values $(\log X$ for values more than $10, \log (x+1)$ for values less than 10 . Means followed by same letter (s) within the column are not significantly different by DMRT at $5 \%$.

\section{Acknowledgements}

We are thankful to the Directorate of Industrial Entomology, Institute of Agriculture and Animal Sciences and Gorkha Honey Bee, Chitwan for providing financial and technical support

\section{References}

Anderson, R.H., B. Buys and M.F. Johannsmeier. 1983. Beekeeping in South Africa. Department of Agriculture Techn. Service, Pretoria, Bull. No. 394, pp.78-79.
APP. 1995. Agriculture perspective plan. Agricultural Projects Services Centre, Kathmandu and John Mellor Associates, Inc., Washington D.C. 337p.

Bhusal, S.J. 2003. Testing of beekeeping technology and its adaptation by farmers. M.Sc. Ag Thesis desertation. Institute of Agriculture and Animal Science, Rampur, Chitwan, Nepal. 120p.

Butler, C.G. 1945. The influence of various physical and biological factors of the environment on honeybee activity. An examination of the relationship between activity and nectar concentration and abundance. J. Expt. Biol. 21: 5-12. 


\section{S. Parajuli \& R. B. Thapa/Foraging Behavior of Apis}

Calderone, N.W. and R.E. Page. 1988. Genotypic variability in age polyethism and task specialization in the honeybee, Apis mellifera L. (Hymenoptera: Apidae). Behav. Ecol. Sociobiol. 22: 17-25.

Entomology Divison. 1966. Annual report 1995-1996. NARC. Khumaltar, Lalitpur, Nepal. 119p.

Gary, N.E., P.C. Witherell and J.M. Martson. 1972. Foraging range and distribution of honeybees used for carrot and onion pollination. En. Ent. 1: 71-78.

Hellmich, R.L., J.M. Kulincewk and W. C. Rothenbuhler 1985. Selection for high and low pollen-hoarding honeybees. J. Hered. 76: 155-158.

Horr, B. 2000. How can we maximize production? Am. Bee J. 140 (7):550-552.

ICIMOD. 1999. Indigenous honeybees of the himalayas: A community based approach to conserving biodiversity and increasing farm productivity. ICIMOD/AUSTRO Project Program, International Centre for Integrated Mountain Development, Kathmandu, Nepal.

Lundie, A.E. 1925. The flight activities of the honeybee. USDA Agric. Bull. 1328.

Mishra, R.C. 1995. Honeybee and their management in India. ICAR, New Delhi, India. 168pp.

Moritz, R.F.A. 1980. Inzuchteffekte auf enzymztischer Ebene bei Dronen von Apis mellifera carnica Pollmann Naturwissenschaften 67:470 (English abstract).

Morse, L. A. and T. Hopper. 1985. The illustrated encyclopedia of beekeeping. Blandorol, U.K. 55p.
Nelson, I.A. and A.P. Sturtevant. 1924. The rate of growth of the honeybee larva. Bull. USDA. Washington DC, USA. 1222: 1-24.

OH, H.W. and S.K. Choi 1986. Duarnal activity of honeybee (Apis mellifera L.) at the hive entrance. Korean J. Apic. 1(2): 85-90.

Oldroyd, B.P., T.E. Rinderer, S.M. Buco and L.D. Beaman. 1993. Genetic variance in honeybees for preferred foraging distance. Anim. Behav. 45: 323-332.

Page, R.E., K.D. Waddingtogn, J. Hunt and M.K. Fondrk. 1995. Genetic determinants of honeybee foraging behavior. Anim. Behav. 50: 1617-1625.

Partap, U. 1997. Bee flora of the Hindukush Himalayas: Inventory and management. ICIMOD, Kathmandu, Nepal. 297p.

Shivakoti, G.P. and S. Bista. 1999. Major constraints in the performance of Apis mellifera and A. cerana under Kathmandu conditions. In: Asian Bees and Beekeeping: (Eds. M. Matsuka, L.R. Verma, S. Wongsiri, K.K. Shrestha \& U. Partap) Progress of Research and Development. Oxford and IBH Pub. Co., Pvt. Ltd., New Delhi, India, pp.29-32.

Thapa, R.B. and D.R. Dangol. 1987/88. A preliminary survey of bee flora at IAAS, Rampur and its vicinity. IAAS Res. Rep. 1985/1991 50-65 pp.

Verma, L.R. 1995. Apis cerana: Biometric, genetic and behavior aspects. In: The Asiatic Hive Bee: Apiculture Biology and Role in Sustainable Development in Tropical and Sub-tropical Asia. (Ed.) P. G. Kevan) Enviroquest Ltd, Canada pp.41-53. 
Nepal Journal of Science and Technology Vol. 13, No. 2 (2012) 51-56 